\title{
Shaping landscapes, remaking knowledges: practices, myths and fire management in Xingu Indigenous Territory (MT, Brazil)
}

\author{
Adryan Nascimento ${ }^{1}$, Katia Ono ${ }^{2}$ e Amanda Horta ${ }^{3}$
}

\footnotetext{
${ }^{1}$ Instituto Socioambiental (ISA). E-mail: adryan@ socioambiental.org

${ }^{2}$ Instituto Socioambiental (ISA). E-mail: katia@ sociambiental.org

${ }^{3}$ Professor at Mato Grosso State University. E-mail: amanda.horta@unemat.br
}

\begin{abstract}
Since 2017 the 16 indigenous communities that inhabit 4 contiguous Indian Reserves at the headwaters of the Xingu River decided to call the entirety of their territories by the name Xingu Indigenous Territory (in portuguese, Território Indígena do Xingu, TIX). This 2,8-million-acre reserve is an important part of a corridor that links protected areas along the Xingu River basin. The TIX concentrates an enormous socioenvironmental diversity, but it is suffering from the climate changes and the hard impacts of the surrounding area occupation based on extensive monocultures. In the past, few decades, wildfires had become increasingly frequent in the territory and its populations observed important changes in the forest's humidity and in the natural signs that guide their management practices. Fire has always been a diversity-generating tool, but it became dangerous, impacting crucial environmental resources. As many old men from different ethnic groups in the TIX usually say, "the fire became angry, big, strong and started to run faster". This paper aims to describe how TIX's peoples are creating a dialogue between traditional knowledge and new techniques for the use of fire, in order to restore environmental balance. Xinguans are seeking to understand these new environmental signs and engaging themselves on new practices of fire management. In this context, the Socio-environmental Institute (in Portuguese, Instituto Socioambiental, ISA) carried out projects to encourage and support indigenous adaptative experiences, techniques and strategies for fire prevention. It also promoted meetings in indigenous villages to reinforce communities' agreements on wise use of fire and its management, based on local forms of social organization. We argue that the only way to achieve these goals is ensuring the participation of TIX's populations on these processes as protagonists. The diversity of landscapes and ways of managing environments contributes to the wise use of fire, which ignites the life in territories, forests and its people.
\end{abstract}

Keywords: fire policies; indigenous fire management; Xingu indigenous territory (TIX). 